\title{
Retinopatía Diabética: Desarrollo, Implicaciones y Herramientas Diagnosticas Novedosas
}

\author{
Diabetic Retinopathy: Development, Implications and Novel Diagnostic Tools \\ Alma Barajas-Espinosa ${ }^{a}$, Ivette Mogica-Bautista ${ }^{b}$, María Marlene Martínez-Morales ${ }^{b}$ Marco \\ Antonio Hernández-Bedolla ${ }^{b}$, Fernando Ochoa-Cortes ${ }^{b}$
}

\begin{abstract}
:
The retina, the visual organ localized in the posterior part of the ocular globe, contains diverse cell types, from the specialized photoreceptors, to neurons and ganglion cells, all of whose metabolic needs are supplied via the retinal microvasculature. This microvasculature niche, composed of endothelial cells and pericytes, is highly sensitive to circulating glucose concentrations. Patients with Type 2 Diabetes, with a poor management of their hyperglycaemia, demonstrate microvasculature damage in several tissues, including the retina. Uncontrolled hyperglycaemia negatively impacts retinal microvasculature, and in the long-term leads to irreversible sight complications as the result of the retinopathy developed. An early diagnosis of the retinopathy would help to diminish the ensuing damage and the associated comorbidities. This revision in aimed at providing basic information about the retina, the pathologic conditions that are set into motion by Type 2 Diabetes, and the usefulness of tear proteins as a diagnostic tool of retinopathy.
\end{abstract}

Keywords:

Diabetic Retinopathy, Proteomics, Tears

Resumen:

La retina, el órgano visual localizado en la parte posterior del glóbulo ocular, contiene diversas células, desde fotorreceptores especializados, hasta células neuronales, células ganglionares, cuyas necesidades metabólicas son suplidas por la microvasculatura retiniana. Dicha microvasculatura, compuesta por células endoteliales y pericitos, es altamente sensible a los niveles de glucosa en la circulación. Pacientes con Diabetes Mellitus tipo 2, con un pobre control glicémico, sufren daños microvasculares en diversos tejidos, incluyendo la retina. La condición de hiperglicemia descontrolada afecta negativamente a la microvasculatura de la retina, y a largo plazo conlleva a complicaciones irreversibles de vista como resultado de la retinopatía que se desarrolla. Un diagnóstico temprano de la retinopatía ayudaría a disminuir el daño ocasionado, y las comorbilidades que resultan. En esta revisión se otorga información básica sobre la retina, las condiciones patológicas que desencadena la Diabetes Tipo 2, y la utilidad del uso de proteómica de lágrimas como herramienta diagnostica de la retinopatía.

Palabras Clave:

Retinopatía Diabética, Proteómica, Lágrimas

\section{The Retina}

The retina, a thin tissue localized in the internal posterior chamber of the eye, is composed of a variety of highlyspecialized cells who function together in order to provide humans with one of their five senses: sight. ${ }^{1}$ The retina can be considered as an extension of the optic nerve, which is one of the cranial nerves and part of the Central Nervous System (CNS). Thus, the retina is itself commonly classified as an extension of the CNS, an extension that begins at the point of entry of the optic nerve and that extends anteriorly, extending until almost touching the lens of the eye, a structure that separates the posterior from the anterior chamber of the eye. Its complex anatomical and physiological organization render it a highly-specialized tissue. The retina is the innermost of the three ocular layers; the medial, or vascular layer, is wherein the choroid is situated along

\footnotetext{
a Autor de Correspondencia, Universidad Autónoma del Estado de Hidalgo, Email: alma_barajas@uaeh.edu.mx

b Universidad Autónoma del Estado de Hidalgo, Email: ivettebautista7@gmail.com, maria_marlene1998@outlook.com, marco_hernandez@uaeh.edu.mx, fernando_ochoa@uaeh.edu.mx
} 
with the ciliary body and the iris; and the external layer is composed of the sclera and the cornea, anteriorly (Figure 1). ${ }^{2}$

The main function of the retina is to capture light, or photons, and convert this light signal into a nervous signal, then to transmit this nervous impulse to the optic nerve. From here, the nervous signal is conveyed to the cerebral cortex, where it will be processed and interpreted accordingly. The microenvironment in which the retinal cells develop and carry out their functions, requires fine regulatory mechanisms, as it is one of the tissues with the highest metabolic demands in the human body. The cell population in the retina is comprised of cones and rods, the photosensitive cells that allow for color vision (the former) and low light vision (the latter). In total, we can distinguish at least eight different cell layers in the retina, from posterior to anterior these include: the pigmented epithelium, the photoreceptor outer and inner segments, the outer nuclear layer, the outer plexiform layer, the inner nuclear layer, the inner plexiform layer and the ganglion cell layer. ${ }^{3}$

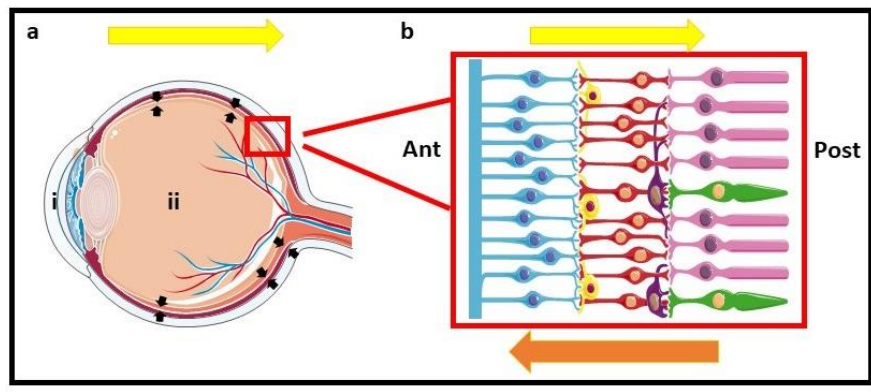

Figure 1. Schematic representation of the human eye and retinal cell layers. A sagittal view of the human eye (a) wherein the retina (black arrows) lies in flat against the internal posterior wall of the eye. Light stimuli (yellow arrow) enters from the anterior (i) chamber, travels to the posterior (ii) chamber of the eye towards the retina. $A$ magnified schematic representation of the retina, the visual sensory portion of the eye, composed of a complex array of well-organized cell layers (b) organized from anterior (Ant) to posterior (Post) and through which the light stimulus must travel (yellow arrow) in order to excite the photosensitive rods (pink) and cones (green). Once stimulated, the photosensitive cells are able to transmit an electrochemical signal (orange arrow) to the neural retinal, that will integrate and transfer the message to the cerebral cortex via the optic nerve.

In addition, there are two specialized areas easily identifiable in the retina: the fovea and the optic disc. The retinal fovea is the thinnest portion of the retina, having a central thickness of approximately 170-182 $\mu \mathrm{m}$, as measured with optical coherence tomography, compared to the thickest portions reported measured at nearly 300 $\mu \mathrm{m} . \quad{ }^{4,5}$ however, within this area we find the greatest concentration of photoreceptors, rendering this portion the greatest visual acuity when compared to the rest of the retina. Conversely, within the area of the optic disc, which is where the ganglion axons bundle up to form the optic nerve, there is no visual perception, rendering it the "blind-spot" region of the retina (Figure 2). ${ }^{6}$

Figure 2. Photograph of eye fundus. Note the vascular network distribution in a normal human retina (a) compared to a retina suffering from diabetic retinopathy (b). In the former, both the optic nerve (ON) disc area is labelled as well as the area corresponding to the fovea
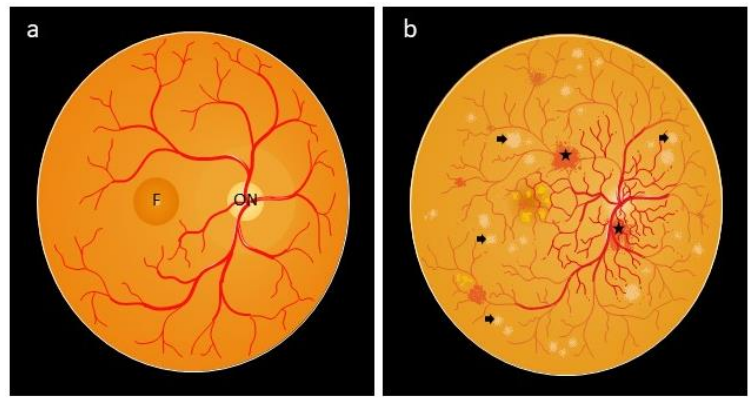

$(F)$. In the latter, a marked vascular regression appears to have occurred, and one can easily localize haemorrhages (stars), and cotton exudates (arrow heads).

\section{Cell Types in the Retina}

As aforementioned, the retina is composed of different cell types of nervous-origin whose rods and cones are highly sensitive to photo-stimuli and which can generate electrochemical signals activated by photon absorption. ${ }^{6}$ Over 150 years have passed since these cells were recognized to be physiologically different, the rods having a far superior sensitivity to light, yet both utilizing similar rhodopsin pigment as the photo-absorbing molecules. These cells are located in the posterior portion of the retina (see Figure 1) and the light path must first cross the retina thickness before actually reaching the photoreceptors. Once absorbed, the photoreceptor transduction of light occurs, a complex mechanism requiring G-proteins, various enzymes (including phosphodiesterase, rhodopsin kinase and guanylyl cyclase and a very prominent active transport of cations $\left(\mathrm{Na}^{+}\right) .{ }^{7}$

Other cell types found in the retina include the horizontal cells, the bipolar cells, the amacrine cells and the ganglion cells. Horizontal cells appear to be important in signal integration; bipolar cells, of which at least nine subtypes have been classified, relay information from the cones to the inner retina; amacrine cells, also interneurons of the retina, are the most diverse anatomically and physiologically, having roles in rod-system integration, and even as dopaminergic neuromodulators; the ganglion cells, considered by some as the true neurons of the retina, as they convey the visual message to the CNS in a region-specific manner. ${ }^{8} 9$ Furthermore, a relatively novel cell type, the microglia, has been identified in mammalian retinae. Microglia are immune cells that reside in the CNS. They have been implicated in regulation of neuronal survival, and in the directing of both neuronal and vascular network establishment in the retina. ${ }^{10}$ 
All of the functions carried out by the various cell types of the retina, including: phototransduction, neurotransmission, cation active transport, protein and phospholipid synthesis, render the retina a tissue with high metabolic demands which in fact have been approximated to be $50 \%$ more than those of the brain. ${ }^{11}$ The accelerated metabolic demand, thus, renders the retina dangerously prone to damage in the event of tissue ischemia.

\section{Vascularization of the Retina}

The retina receives nutrients and oxygen via two separate vascular networks, one which irrigates the inner retina and the other which supplies the outer retina. These vascular networks are derived from the central retinal artery and the choroid plexus, respectively. As already mentioned, the retinal tissue has a high metabolic demand, and thus it becomes imperative that the retina receive the required irrigation, to avoid retinal cell loss ${ }^{12}$ and tissue edema, events that could significantly impair vision. ${ }^{13}$ Moreover, as the incoming light source must necessarily transverse the entire thickness of the retina to reach and stimulate the photoreceptors localized in the posterior of the retina, it is very important that the inner retinal vascular network is adequately organized so that it does not interfere, or diffract the incoming light.

\section{Diabetic Retinopathy}

According to the International Diabetic Foundation, in the year 2015, 415 million people worldwide had diabetes and this staggering number is expected to increase to 642 million by the year 2040. The World Health Organization has classified diabetic retinopathy (DR), a chronic pathophysiological condition brought on by prolonged and/or uncontrolled Diabetes, as a priority eye disease. ${ }^{14}$ In the Mexican population, approximately $31.5 \%$ of the diabetic patients suffering from diabetes have also developed DR. Incidence of DR incidence increases accordingly with diabetes duration. At 5-10 years postdiabetes onset, $27 \%$ of patients develop DR, whereas a duration of $10-19$ years results in $90 \%$ probability of developing DR. Post-twenty years of diabetes duration, $95 \%$ of patients develop DR and, of these, $30-50 \%$ reach the proliferative phase of DR. ${ }^{15}$

Diabetic retinopathy is a progressive degenerative disease, linked to unregulated hyperglycemic states, and is recognized as the main cause of visual incapacity in working-age adults. It has been duly noted that prior to the vascular damage that characterizes DR, patients demonstrate alterations to their neurosensory perception. Once in an advanced stage, DR is characterized by the formation of microaneurysms and intraretinal hemorrhages, microvascular lesions that lead to a significant decrease in retinal capillary perfusion, as well as cotton exudates, venal alterations and intraretinal microvascular anomalies. ${ }^{16}$ When the flow to the retina becomes diminished, and is no longer able to supply the required nutrients and oxygenation to this demanding tissue, the retina begins to suffer ischemia. Ischemic events such as these lead to an increase in vascular permeability and ultimately result in edema of the tissue, a tissue response that leads to retinal damage. ${ }^{13}$ The retinal vascular network can even deteriorate, starting with the pericytes, the contractile cells that cover the capillaries, and followed by the endothelium cells. These pericytes, indeed appear to play different roles, including that of controlling local blood flow, sensing vasoactive peptides and cell-to-cell signalling mechanisms. 1217 In the proliferative phase of DR, there is profound neovascularization that follows the stimuli of ischemia, and these new, aberrant vessels project anteriorly into the vitreous humor, causing retinal detachment. 18 Proliferative DR has been documented to affect around $65 \%$ of patients who have suffered diabetes for $30-34$ years. ${ }^{19}$

The prevalence and development of DR are brought on by a poor control of glycemic levels. In fact, increased circulating glucose levels are considered a major significant risk factor, as it directly exerts an effect on the luminal endothelium membrane of the vasculature, as well as promoting protein glycosylation. ${ }^{20,21}$

\section{Pericyte Stability and DR}

One of the crucial events leading up to the development of DR is the loss of vascular pericytes, particularly those found in retinal capillaries. ${ }^{22}$ Following pericyte cell detachment and death, hemorrhages and microaneurysms follow, cotton exudates set in, new vessels form (neovascularization) and vitreous hemorrhages ensue. ${ }^{23}$ Pericytes are mural cells located on the basal membrane of capillary endothelium cells. They possess contractile proteins and, similar to smooth muscle cells, are capable of contracting. In fact, this contractile ability is precisely what allows them to finetune the capillary tone and adjust blood flow to tissue requirements. Moreover, pericytes serve a nurturing function as well, providing a scaffolding for vessel growth, and endothelial cell maintenance. In view of these functions, one can decipher the events that follow pericyte loss in the retinal vasculature: vascular dysfunction, increased vascular permeability, and eventual vascular regression. All of these events result in a lack of proper blood flow to the retina tissue, ischemic events, edema, novel aberrant vessel sprouting, retinal detachment, and severe visual impairment. In fact, both pericytes and endothelial vascular cells display a high sensitivity to hyperglycemia. Pericytes are known to respond to this harmful stimulus by detaching from the capillary and dying, while endothelial cells appear to change to an apoptotic phenotype themselves. 24 Prolonged hyperglycemia also leads to protein glycosylation in the basal capillary membrane and in pathological changes in the collagen structure in the extravascular matrix, producing a matrix with greater permeability to large molecules including lipoproteins and plasma proteins. ${ }^{23 \text {, }}$ 25,26

\section{Complications Associated with DR}

Diabetic retinopathy has a negative impact on those affected, an impact measurable by both psychological parameters and physical parameters. Several studies have found that patients with DR have a lower quality of 
life and life satisfaction perception. 27 Reasonably, diabetes itself has a negative impact, yet patients who had developed DR complications associated with diabetes demonstrated a statistically significant lower quality of life than those who had no retinal complications. In fact, there was a positive correlation between severity of DR and a lower life quality in patients studied. 27, 28 Physically speaking, DR leads to significant ocular complications that precede blindness, these include: vitreous hemorrhaging, retinal detachment, and neovascular glaucoma.

Vitreous hemorrhaging typically occurs as a collateral effect of proliferative diabetic retinopathy, wherein the nascent vasculature is unstable and easily tears and bleeds into the vitreous chamber. The hemorrhagic events typically occur at night, and may be perceived by the patient upon waking up in the morning as a loss of vision. ${ }^{29}$ The hemorrhage will self-absorb within weeks when it is small; however, when the hemorrhage is more severe, treatment options for this complication primarily involve laser photocoagulation, or vitrectomy coupled with panretinal photocoagulation in the even that the hemorrhage does not clear with the first treatment option. 30 Traction retinal detachment, which involves the detachment of the entire temporal portion of the retina, can occur directly as a side-effect of DR, this complication is considered an advanced pathology of DR as it presents the technically complicated surgery of small-gauge vitrectomy. This surgery procedure involves removal of fibrous membranes and a vitreous tamponade, which can be either a gas or silicone oil, that prevents fluid build-up in the subretinal space and thus allows the retina to reaccomodate naturally post-surgery. ${ }^{31}$ Another associated complication of DR is the development of vascular networks in the iris and anterior chamber angle, obstructing thus the drainage of the anterior chamber of the eye, and resulting in aqueous humor build-up and intraocular pressure increase, or glaucoma. This type of glaucoma, termed neovascular glaucoma, is mainly caused by proliferative DR. ${ }^{32}$

An interesting fact is that not all diabetic patients develop $\mathrm{DR}$, a fact which has led to extensive research for the determinants of this complication. There is a general consensus regarding some of the personal risk factors which increase the probability of developing DR. Amongst these, the duration of the disease appears to be the most potent determinant. However, other identified risk factors include: insulin-dependence, total serum cholesterol levels, proteinuria, low hemoglobin and hematocrit levels. ${ }^{33}$

\section{Diagnostic Tools}

During the past decade, diagnosis of DR has become one of the greatest challenges in the ophthalmologic realm. A particularly tricky situation is that most of the patients suffering from DR do not themselves perceive signs or symptoms of the pathology, a situation that leads to late stage diagnosis when the disease has progressed to a more severe format. For some countries, and this is largely dependent on the magnitude of human and economic resources, DR is typically diagnosed in its moderate or severe stages and the diagnosis is most commonly performed employing retinal photographic images, visual acuity tests, tonometry parameters, biomicroscopy, gonioscopy, and other direct or indirect ophthalmologic techniques. ${ }^{34}$ However, these types of eye exams require specialized professionals, the tests are costly and patients need to travel to a health clinic or hospital to have them performed. Perhaps it is not, thus, surprising that DR is the main cause of blindness in people age 20-64 years. Globally, the number of patients affected increases by $10 \%$ on a yearly basis, and this staggering statistic has propelled researchers to find and develop new tools for the diagnosis, monitoring, and treatment of DR. ${ }^{35,36}$

Up until a few years ago, the use of "biomarkers" focused on the study of ophthalmic pathologies, had not even been an area of study or consideration. The term, biomarker, references biological molecules produced by the organism in response to normal or pathological states, or in response to an external stimulus. Therefore, in theory, one could identify and quantify a biomarker, and use this information to extrapolate the individual's state of health. However, before one can begin using biomarkers as predictive of human disease, it is fundamental that the biomarker's reliability in the interpretation first be thoroughly assessed. 37,38

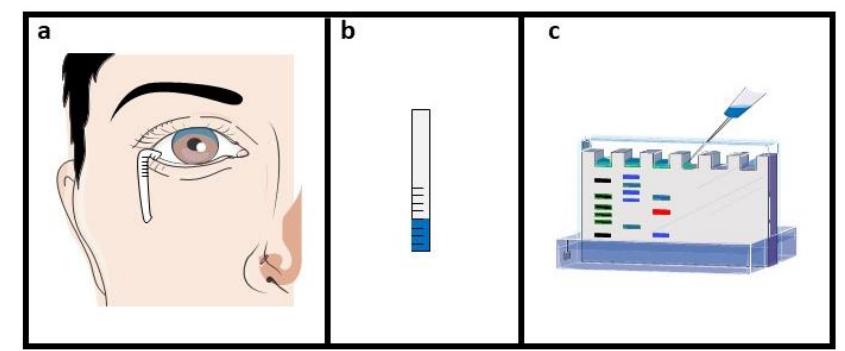

Figure 3. Novel diagnostic tool. Using Schirmer's filter strips, these can be easily and painlessly inserted in the external lower eye lid for tear collection (a). The total volume collected can be measured by visualizing the markings on the Schirmer strip (b) and the protein contents analyzed using a proteomic approach (c).

After intensive research, it has now become clear that patients with DR suffer significant changes in the protein makeup of their ocular tissue, as assessed by examination of the biofluids: aqueous humour, serum, vitreal humour, and tears. ${ }^{39,40}$ However, as the collection of intraocular fluids require invasive techniques, highly trained personnel, and specialized equipment, their use is hardly an improvement over the classical direct or indirect ophthalmologic techniques mentioned previously. Tears 
are a biofluid composed of lipids, proteins, metabolic products, enzymes, salts and water. They are accessible all of the time, and collection of tear fluid is quite noninvasive, transportable, simple, and cheap to perform. Several different collection methods have been tested; the method of choice requires the use of filter paper strips called Schirmer strips (Figure 3). The sterile, individuallypackaged strips are slightly folded and carefully placed in the external lower eye lid. The tear donor is asked to continue as normal, as the filter paper absorbs tear fluid in a painless fashion for a determined time period (typically 5-10 min). 41, 39, 42 The absorbed tear fluid can then be transported to a laboratory for processing, and identification of its protein contents carried out using a proteomic approach. Amongst the biomarkers identified as indicative of DR are: serum amyloid A proteins, Interleukin-6, apolipoprotein $\alpha-1$, $\alpha-2$, antithrombin, glycation end-products, amongst others. The specificity of these peptides is in process of determination, and trials are underway to develop automatized methods for tear content separation and identification, that can offer a more precise molecular fingerprint of ocular tissue suffering from DR. 43, 44 Undoubtedly, the incorporation of proteomics in the timely diagnosis of DR will allow for increased diagnostic efficiency and earlier treatment of the pathology. Altogether the overall aim is to improve the morbidity associated with this devastating disease.

\section{Conclusion}

As the aim of this revision was to provide basic information regarding the anatomical structure and physiological requirements of the retina, the visual organ located in the posterior chamber of the eye. The retina is a thin (less than $300 \mu \mathrm{m})$ organ composed of specialized photosensitive cells, neurons, glial cells. Due to its high metabolic demands, it requires a constant blood supply which it receives via the numerous capillaries and arterioles that emanate from the central retinal artery. This microvascular complex, composed of endothelium, smooth muscle and pericytes, becomes damaged under conditions of prolonged hyperglycemia, as experienced by patients with Type 2 Diabetes. Vascular dysfunction leads, inevitably, to tissue damage and loss of vision. Novel detection methods are aimed at the early detection of state-specific biomarkers in lacrimal fluid. However, this diagnostic tool still requires the ongoing search for specific biomarkers of the retinopathy, a search that employing a proteomic approach to the analysis of tear fluid collected from patients with diabetic retinopathy. Early detection of diabetic retinopathy could allow for a timely application of treatment options and, hopefully, the safeguarding of one of humanity's most prized senses: sight.

\section{Funding}

This work was made possible thanks to the funding of the project awarded to AB-E (PRODEP-2019-0045) by the Secretaria de Educación Pública. IM-B was awarded a student scholarship under the same project.

\section{Acknowledgements}

\section{Figures were adapted from Servier Medical Art, https://smart.servier.com/, under the Creative Commons Attribution 3.0.}

\section{Referencias}

1. Fernández Pérez S, de Dios Lorente J, Peña Sisto L, García Espinosa, SM; León Leal M. Causas más frecuentes de consulta oftalmológica. MEDISAN. 2009;13(3):1-12.

2. Uchoa Junqueira L, Mescher A. Junqueira's Basic Histology: Text and Atlas. 12th ed. New York: McGraw-Hill Medical; 2010.

3. Bosco A, Lerário AC, Ferreira R, Galvão D, Franco ACHM, Retinopathy D. Retinopatia Diabética. Arq Bras Endocrinol Meta. 2005;49(2):217-227.

4. Chan A, Duker JS, Ko TH, Fujimoto JG, Schuman JS. Normal macular thickness measurements in healthy eyes using stratus optical coherence tomography. Arch Ophthalmol. 2006;124(2):193-198. doi:10.1001/archopht.124.2.193

5. Grover S, Murthy RK, Brar VS, Chalam K V. Comparison of retinal thickness in normal eyes using stratus and spectralis optical coherence tomography. Investig Ophthalmol Vis Sci. 2010;51(5):2644-2647. doi:10.1167/iovs.09-4774

6. Cano Reyes, JdelC; Infante Tavio, NI; Gonzalez Guerrero, L; Fernandez Perez, SR; Herrera Cutie D. Desprendimiento de retina: una revisión bibliográfica necesaria. Medisan. 2015;19(1):78-87.

7. Ingram N, Sampath A, Fain G. Why are rods more sensitive than cones? J Physiol. 2016;19:5415-5426.

8. Hoon M, Okawa H, Della Santina L, Wong ROL. Functional architecture of the retina: Development and disease. Prog Retin Eye Res. 2014;42(i):44-84. doi:10.1016/j.preteyeres.2014.06.003

9. Masland RH. Cell populations of the retina: The proctor lecture. Investig Ophthalmol Vis Sci. 2011;52(7):4581-4591. doi:10.1167/iovs.10-7083

10. Silverman SM, Wong WT. Microglia in the retina: Roles in development, maturity, and disease. Annu Rev Vis Sci. 2018;4(May):45-77. doi:10.1146/annurev-vision-091517-034425

11. Ames A. Energy requirements of CNS cells as related to their function and to their vulnerability to ischemia: A commentary based on studies on retina. Can J Physiol Pharmacol. 1992;70(SUPPL.). doi:10.1139/y92-257

12. Puro DG. Physiology and pathobiology of the pericyte-containing retinal microvasculature: New developments. Microcirculation. 2007;14(1):1-10. doi:10.1080/10739680601072099

13. Barajas-Espinosa A, Ni NC, Yan D, Zarini S, Murphy RC, Funk CD. The cysteinyl leukotriene 2 receptor mediates retinal edema and pathological neovascularization in a murine model of oxygen-induced retinopathy. FASEB J. 2012;26(3). doi:10.1096/fj.11-195792 
14. World Health Organization. Blindness and vision impairment prevention.

https://www.who.int/blindness/causes/priority/en/index5.html.

15. Instituto Mexicano del Seguro. GUÍA DE PRÁCTICA CLÍNICA GPC Diagnóstico y Tratamiento de RETINOPATÍA DIABÉTICA Evidencias y Recomendaciones Catálogo Maestro de Guías de Práctica Clínica: IMSS-171-09.; 2015. www.cenetec.salud.gob.mx.

16. Lechner J, O'Leary OE, Stitt AW. The pathology associated with diabetic retinopathy. Vision Res. 2017;139:7-14. doi:10.1016/j.visres.2017.04.003

17. Shibata M, Ishizaki E, Zhang T, et al. Purinergic vasotoxicity: Role of the pore/oxidant/katp channel/ca2+ pathway in $\mathrm{p} 2 \times 7$-induced cell death in retinal capillaries. Vis. 2018;2(3). doi:10.3390/vision2030025

18. Joyal JS, Gantner ML, Smith LEH. Retinal energy demands control vascular supply of the retina in development and disease: The role of neuronal lipid and glucose metabolism. Prog Retin Eye Res. 2018;64:131-156. doi:10.1016/j.preteyeres.2017.11.002

19. Klein R, Klein BE, Moss SE. Epidemiology pf Proliferative Diabetic Retinopathy. Diabetes Care. 1992;15(12):1875-1891.

20. Schreur V, van Asten F, Ng H, et al. Risk factors for development and progression of diabetic retinopathy in Dutch patients with type 1 diabetes mellitus. Acta Ophthalmol. 2018;96(5):459-464 doi:10.1111/aos.13815

21. Hernandez Perez A, Tirado Martinez O, Rivas Canino M, Licea Puig M, Maciquez Rodriguez J. Factores de Riesgo en el Desarrollo de la Retinopatia Diabetica. Rev Cuba Oftalmol. 2011;24(1):86-99.

22. Beltramo E, Porta M. Pericyte Loss in Diabetic Retinopathy: Mechanisms and Consequences. Curr Med Chem. 2013;20(26):3218 3225 .

23. Olmos P, Araya-Del-Pino A, González C, Laso P, Irribarra V, Rubio L. Fisiopatología de la retinopatía y nefropatía diabéticas. Rev Med Chil. 2009:137(10):1375-1384. doi:10.4067/s0034-98872009001000015

24. Liu C, Ge HM, Liu BH, et al. Targeting pericyte-endothelial cell crosstalk by circular RNA-cPWWP2A inhibition aggravates diabetesinduced microvascular dysfunction. Proc Natl Acad Sci U S A. 2019;116(15):7455-7464. doi:10.1073/pnas.1814874116

25. Klaassen I, Van Noorden CJF, Schlingemann RO. Molecular basis of the inner blood-retinal barrier and its breakdown in diabetic macular edema and other pathological conditions. Prog Retin Eye Res. 2013;34(February):19-48. doi:10.1016/j.preteyeres.2013.02.001

26. Aronson D, Rayfield EJ. How hyperglycemia promotes atherosclerosis: Molecular mechanisms. Cardiovasc Diabetol. 2002;1:1-10. doi:10.1186/1475-2840-1-1

27. Ligda G, Ploubidis D, Foteli S, Kontou PI, Nikolaou C, Tentolouris N. Quality of life in subjects with type 2 diabetes mellitus with diabetic retinopathy: A case-control study. Diabetes Metab Syndr Clin Res Rev. 2019;13(2):947-952. doi:10.1016/j.dsx.2018.12.012

28. Alcubierre N, Rubinat E, Traveset A, et al. A prospective cross-sectional study on quality of life and treatment satisfaction in type 2 diabetic patients with retinopathy without other major late diabetic complications. Health Qual Life Outcomes. 2014;12(1):1-12. doi:10.1186/s12955-014-0131-2

29. Andonegui Navarro J, Baget Bernaldiz M, Casaroli-Marano R, et al Exploración Del Fondo de Ojo En Atención Primaria. (Romero Aroca P, ed.). Baladona: Euromedice; 2011.
30. Annan J, Carvounis P. Current Management of Vitreous Hemorrhage due to Proliferative Diabetic Retinopathy. Int Opthalmological Clin. 2014;54(2):141-153. doi:10.1097/IIO.0000000000000027.Current

31. Stewart M, Browning D, Landers M. Current management of diabetic tractional retinal detachments. Indian J Ophthalmol. 2018;66(12):17511762.

32. Kwon JW, Jee D, La TY. Neovascular glaucoma after vitrectomy in patients with proliferative diabetic retinopathy. Med (United States). 2017:96(10). doi:10.1097/MD.0000000000006263

33. da Silva Corea Z, Morael Freitas A, Mundialino Marcon I. Risk factors related to the severity of diabetic retinopathy. Arq Bras Oftalmol. 2003;66(5):739-743

34. Cenetec PP. GUÍA DE PRÁCTICA CLÍNICA GPC Diagnóstico y tratamiento de RETINOPATÍA DIABÉTICA Evidencias y Recomendaciones Catálogo Maestro de Guías de Práctica Clínica: IMSS-171-09. 2015. www.cenetec.salud.gob.mx.

35. Prado-Serrano A, Guido-Jiménez M, Camas-Benítez J. Prevalencia de retinopatía diabética en población mexicana. Rev Mex Oftalmol. 2009;83(5):261-266. Rev Mex Oftalmol. 2009;83(5):261-266.

36. Csősz É, Deák E, Kalló G, Csutak A, Tőzsér J. Diabetic retinopathy: Proteomic approaches to help the differential diagnosis and to understand the underlying molecular mechanisms. J Proteomics. 2017;150:351-358. doi:10.1016/j.jprot.2016.06.034

37. Ting D, Tan K, Phua V, GSW T, CW W, Wong T. Biomarkers of Diabetic Retinopathy. Curr Diab Rep. 2016;16(12). doi:ttps://doi.org/10.1007/s11892-016-0812-9

38. Foxhall L, Rodriguez M. Cardiovascular Issues. In: Advances in Cancer Survivorship Management. Springer New York LLC; 2015:325-334

39. Hagan S, Martin E, Enríquez-de-Salamanca A. Tear fluid biomarkers in ocular and systemic disease: Potential use for predictive, preventive and personalised medicine. EPMA J. 2016;7(1):1-20. doi:10.1186/s13167016-0065-3

40. Grus FH, Joachim SC, Pfeiffer N. Proteomics in ocular fluids. $\begin{array}{llll}\text { Proteomics } & - & \text { Clin } & \text { Appl. 2007;1(8):876-888. }\end{array}$ doi:10.1002/prca.200700105

41. von Thun und Hohenstein-Blaul N, Funke S, Grus FH. Tears as a source of biomarkers for ocular and systemic diseases. Exp Eye Res. 2013;117:126-137. doi:10.1016/j.exer.2013.07.015

42. García-Porta N, Mann A, Sáez-Martínez V, Franklin V, Wolffsohn JS, Tighe B. The potential influence of Schirmer strip variables on dry eye disease characterisation, and on tear collection and analysis. Contact Lens Anterior Eye. 2018;41(1):47-53. doi:10.1016/j.clae.2017.09.012

43. Torok Z, Peto T, Csosz E, et al. Combined Methods for Diabetic Retinopathy Screening, Using Retina Photographs and Tear Fluid Proteomics Biomarkers. J Diabetes Res. 2015:1-8. doi:10.1155/2015/623619

44. Kim HJ, Kim PK, Yoo HS, Kim CW. Comparison of tear proteins between healthy and early diabetic retinopathy patients. Clin Biochem. 2012;45:60-67. doi:10.1016/j.clinbiochem.2011.10.006 